\title{
Brain-Computer Interface and Neurofeedback Technologies: Current State, Problems and Clinical Prospects (Review)
}

\author{
DOI: 10.17691/stm2017.9.1.22
}

Received October 4, 2016

A.I. Fedotchev, DSc, Leading Researcher, Laboratory of Reception Mechanisms

S.B. Parin, DSc, Head of the Laboratory of Psychophysiology2;

S.A. Polevaya, DSc, Head of the Department of Psychophysiology2; Head of the Department of Neurophysiology and Experimental Modelling, Central Scientific Research Laboratory ${ }^{3}$;

S.D. Velikova, DSc, Scientific Consultant, Department of Neurophysiology and Experimental Modelling, Central Scientific Research Laboratory ${ }^{3}$

${ }^{1}$ Institute of Cell Biophysics, Russian Academy of Sciences, 3 Institutskaya St., Pushchino, Moscow Region, 142290, Russian Federation;

2Lobachevsky State University of Nizhni Novgorod, 23 Prospekt Gagarina, Nizhny Novgorod, 603950,

Russian Federation;

${ }^{3}$ Nizhny Novgorod State Medical Academy, 10/1 Minin and Pozharsky Square, Nizhny Novgorod, 603005,

Russian Federation

\begin{abstract}
Brain-computer interface and neurofeedback technologies are unique techniques to modulate brain activity based on an operant conditioning. From the time these technologies appeared in the 60 -ies of the XX c., they have become non-drug tools for numerous psychiatric and neurologic disorders. However, up to now their efficiency is a matter of debate. Our review considers the background, characteristic features and current state of the technologies. The emphasis was made on the analysis of capabilities and prospects of the technologies in clinical medicine to mobilize the plasticity mechanisms of brain neural network. The review presents the findings of our own experiments showing the future of brain-computer interface and neurofeedback technologies to depend on multi-type cooperation of neurologists, neurobiologists, engineers and mathematicians. Effective consolidation of several fields of science will enable to develop novel therapeutic regimens to restore and improve neural, cognitive and behavioral functions.
\end{abstract}

Key words: bioelectric control; brain-computer interface; neurofeedback; electroencephalogram; EEG.

In the second half of the last century neurophysiologists made a breakthrough. They stated that the body functions formerly thought as involuntary and without self-regulation can under certain conditions be human controlled. The main condition is that a human by means of various facilities receives feedback signals on a current body state. The discovery resulted in two independent research lines based on the use of feedback signals from human brain potentials to control its functions.

The first research trend is based on bioelectric control and associated with computer information management systems mediating the communication between the brain and different devices. The technologies were called brain-computer interface $(\mathrm{BCl})$. They enable a human to control a computer and other devices using brain signals recorded on the head surface in a form of an electroencephalogram (EEG), i.e. avoiding data transfer by nerves and muscles [1].

The second trend is based on I.P. Pavlov theory of conditioned reflexes and its development in the studies devoted to human EEG operant conditioning [2]. Due to the researches showing the capabilities of voluntary rearrangement and overfitting of brain wave patterns using a conditioning principle there was formed a biocontrol technology with feedback by EEG, or neurofeedback (NFB) [3].

Both technologies have common features, as well as differences. The presence of common features enabled some researchers either to consider them together [4] or regard NFB technology as one of the earliest applications of $\mathrm{BCl}$ technology [5], or its special case aimed at using external feedback rather than control an external device to model certain aspects of a physiological brain signal [6]. The main difference of these two approaches is in the ratio of automatic and controlled feedback processing of signals from brain potentials. If in $\mathrm{BCl}$ these signals do not require perception automatically controlling operational units, or modeling the parameters of external actions, then in NFB, brain potentials are converted to informational feedback signals to teach a human for conscious voluntary regulation of his own functions.

Currently, there is an intense interest in both research trends. It manifested, primarily, in a great number of

For contacts: Alexander I. Fedotchev, e-mail: fedotchev@mail.ru 
analytical reviews on various aspects of neurointerfaces [7-21]. In addition, over the last 5 years, the publications on $\mathrm{BCl}$ and NFB in PubMed have increased by 2-3 times. Such exponential growth of researchers, different authors link to inefficiency of conventional techniques of pharmacological treatment [22-26], with more thorough understanding of brain plasticity mechanisms and increasing dissatisfaction with current rehabilitation methods [27-29], as well as with rapid growth of computational capacities, robotized technologies, techniques for brain signal recording and mathematical algorithms for their decoding [30].

The abundance of recent publications on the issue and a great variety of the methods used make it difficult to assess generally the situation in this field of knowledge, and distinguish the approaches to the utmost appropriate for clinical medicine. The present review has summarized the reports in literature over the last 5 years on the essence, characteristics and current state of $\mathrm{BCl}$ and NFB technologies. Particular attention is given to the capabilities and prospects of these technologies in medicine. The findings of the authors in this field have been presented.

\section{Brain-computer interface}

Brain-computer interface is a computer information management system, which records brain signals, analyzes and transforms them into commands coming to output devices to perform desired actions. According to the definition, $\mathrm{BCl}$ is a system measuring the brain activity and transforming it into an artificial output signal, which substitutes, recovers, triggers, supports, informs or improves a natural output signal, and in such a way, changes the current interactions of the brain with external and internal environments [31].

The year 1973 is considered to be the origin of $\mathrm{BCl}$ technology, when a term "brain-computer interface" was suggested, and there was set a plan of experimental studies on human brain-computer interaction [32]. However, there is every reason to believe that the trend is based on a bioelectric control technique, which was formed in 50-60-ies of the last century, and is developing rapidly nowadays. It presupposes the use of bioelectric potentials generated by human tissues or organs for automatic control of various external devices [33]. A perfect example of the trend is a pioneer work by N.P. Bekhtereva demonstrating a rhythmical photic stimulation automatically controlled by the patient's brain electric signals to result in the increase in abundance of EEG alpha activity and being the most effective type of a functional load than common photostimulation types [34]. Subsequently, different variants of this approach were used abroad for the treatment purposes, and were called "EEG-driven photic stimulation" or "alpha power dependent light stimulation" [35-37].

The major goal of $\mathrm{BCl}$ technology is in the substitution or recovery of useful functions for individuals unable to perform them due to neuromuscular disorders, such as amyotrophic sclerosis, cerebral palsy, stroke or spinal injury [38-41].

Brain-computer interface is one of the most promising technologies in the sphere of treatment of neurological conditions and injuries. It enables to establish the communication between intact brain areas and auxiliary devices, which makes it possible to compensate motor and sensory functions. For example, the patients paralyzed due to spinal fracture, can restore their mobility using $\mathrm{BCl}$, which connects neuronal structures of the motor cortex with robotic arms, exoskeletons or neuromorphic electrogenerators [42]. Moreover, sensory $\mathrm{BCl}$ can serve to recovery the sensitivity of paralyzed body parts by transmitting somatosensory sensations of touch, temperature, pain and vibrations in these patients [43]. There are some achievements in $\mathrm{BCl}$ development $[44,45]$ including those made in Russia [46-50].

In addition to neurostimulators aimed, mainly, at motor function recovering, $\mathrm{BCl}$ with an auxiliary function hold a prominent place in rehabilitation medicine. $\mathrm{BCl}$ makes it possible for patients, by acts of will, to type on a monitor screen, press virtual on-off buttons available for their self-maintenance, user devices of hospital beds, etc. The complex of such $\mathrm{BCl}$ systems assisting a patient can be called neurocommunicators, since they, in their own way, help a human without any muscular movements to choose certain symbols to type a text or a command on a computer screen [51, 52].

\section{Neurofeedback}

Neurofeedback technology is a computer information management system, which enables to modify brain biopotentials with an active participation of a patient himself. To accomplish this, a current amplitude of a certain EEG-rhythm using various computer means is reflected in parameters of light and/or audio feedback signals showing to a patient in order to teach him a conscious brain control of the intensity of own rhythmic EEG components to achieve desirable curative effects. If a human in real time can hear or see an adequate reflection of his own biopotentials, then he has an opportunity to learn to change them in a direction required. At first the achieved effects are short-term, but in the course of training in most people this skill is reinforced. Thus, NFB offers auxiliary facilities for nondrug rehabilitation of various brain pathologies [53].

In general, NFB system consists of five elements or processing steps: a brain signal reception, signal preliminary processing, distinguishing key features, feedback signal generation, and an adaptive training. After EEG recording, the data are preliminarily processed (e.g., artifact detection, removal, and correction), with generation and selection of features, and feedback signal computation and notation. The last step closes the feedback circuit, where a participant attempts to learn to use a feedback signal to change the 
brain activity according to instructions. All the necessary steps are taken on a real-time basis. The distinguished features, as a rule, reflect quantitatively the activity level of a certain brain area or network, and a feedback signal transmits the information on the corresponding changes in the brain condition. Participants are trained to find and adapt the strategies in order to change intentionally the state of their brains in accordance with the preliminary instructions [5].

An initial stage of establishing NFB technology was a series of researches carried out by Kamiya in the 60-ies of the last century, which demonstrated the human capability to change voluntarily the intensity of spectral components of his own EEG [54]. Subsequently, this fact served as the basis for development a number of clinical NFB applications to treat many diseases through direct rearrangement of electric processes in brain.

The mechanisms of therapeutic action of NFB are still unclarified, though many studies are devoted to their understanding [55-58]. According to one concept, potential mechanisms of NFB are rearrangements of neural networks including the increase in their global interconnection and neuroplasticity [59]. Other researchers consider NFB to perform the adjustment of brain electric activity vibrations set up for such a homeostatic level, which provides an optimal balance between neural network flexibility and stability [60].

By present time there has been gained positive clinical experience of NFB application for a wide range of diseases. Among them there are attention deficithyperactivity disorder [61-65], learning disability [66], stroke [67], traumatic brain injury [68], uncontrolled epilepsy [69], substance abuse [70-72], depression [73], autism [74], migraine [75], eating disorders [76], pain syndromes $[77,78]$ and other pathologic conditions. It should be noted that regardless the origin of symptoms, NFB training hold out auxiliary facilities for rehabilitation through direct re-education of electric processes in the brain.

In literature one can encounter the data on curative effects of NFB application in psychiatric disorders, such as eating disorders, schizophrenia and psychoses [79], to treat the function of executive control in Tourette syndrome [80], as well as for recovery and improvement of functions in high performance sport [81].

It is worth mentioning that there are conflicting opinions on NFB efficiency in the treatment of various pathological conditions and disorders. Some authors consider NFB to be certainly effective and specific cure for epilepsy, attention deficit-hyperactivity disorder and anxiety disorders, probably effective - in the treatment of brain injuries, drug addiction and insomnia, and insufficiently effective - in depressive disorders, autism and posttraumatic stress disorders [23]. Other authors when studying the reports in literature have come to the conclusion that NFB is effective in autistic spectrum disorders, drug intervention, and brain injury consequences [59]. There is one more group of authors, who think NFB to be a potentially clinical tool in severe neuropsychiatric disorders: schizophrenia, depression, Parkinson disease, etc. [82].

\section{Problems and prospects of brain-computer interface and neurofeedback technologies}

In spite of international recognition of the topic significance, specialized scientific journals, there are still a number of problems in $\mathrm{BCl}$ and $\mathrm{NFB}$ studies requiring solution.

For $\mathrm{BCl}$ technology optimization, two major tasks should be completed. Firstly, there should be selected the most dynamic biometric signals with the following distinguishing from them reliable markers of human mental efforts. The second task is to develop greatly individualized schedules of the procedure to form a command mental effort, which should result in clear and stable changes in the recorded electrographic or metabolic indices [52].

A progress is needed in the development of invasive and noninvasive $\mathrm{BCl}$, as well as in the development of techniques of precisely targeted stimulation of brain or sensory channels with high spatial and temporal resolution to substitute the lost sensory inputs (e.g., touch sensation prosthesis in amputees), an immediate correction of dysfunctional networks (e.g., detection and mitigation of neuronal activity disturbance) and a longterm recovery of healthy functional networks through the use of brain plasticity neural mechanisms [45]. As a result, a new trend in medicine will advance neuroprosthetics, or interdisciplinary research area including neuroscience, computer science, physiology, and biomedical engineering to substitute or recover motor, sensory or cognitive functions that could be damaged due to an injury or a disease [83].

There are many pending questions and problems in NFB. Some authors emphasize an insignificant number of strictly controlled studies and minimal samples used in the investigations devoted to different NFB variants despite the positive findings [23]. Other researchers analyzing the studies on NFB indicate such problems as: no adequate selection of an experiment design, an inadequate use of controlled conditions and control groups of test subjects, the lack of concepts of learning mechanisms participating in brain self-regulation [82].

Clinical prospects of NFB are thought to depend directly on the solution of the above-mentioned and other methodological problems, as well as the wider use of modern live brain imaging technologies (e.g., functional magnetic resonance tomography in a real-time mode, or near infrared spectroscopy). The utilization of the technologies using stricter research protocols will enable to throw light on in-deep NFB mechanisms, which are to contribute to the development of more effective clinical applications of neurointerfaces [84].

Two advanced tendencies can be distinguished in current studies on $\mathrm{BCl}$ and NFB. One of them is 
related to the use of individually revealed specific EEG components instead of overmuch wide-band, predetermined traditional EEG rhythms [85]. According to some works $[63,86]$, such approach leads to the significant improving of treatment procedure efficiency. The second tendency consists in the combination of neurointerface technologies with other ones: transcranial magnetic stimulation [87] or audio-visual stimulation [88] that also improves the efficiency.

\section{Musical neurointerface}

One of the major problems in NFB technology is that of optimal organization of feedback signals as a key factor determining the success in biocontrol $[89,90]$. However, the most promising approach to the organization of NFB procedures is a combined exploration focused on the interaction between the human brain, body and behavior [91]. The technology of musical NFB developed by the authors is just the technology combining the utmost individuality of biocontrol and the benefit of unconscious perception of the stimuli typical for musical therapy [92, 93].

The approach is based on the use of musical or musiclike stimuli, which are organized in strict accordance with the current values of patient's brain biopotentials. The characteristic feature of the technique is a musical feedback from narrow-frequency EEG-oscillators typical and relevant for an individual, and revealed in a real time mode based on a specifically developed dynamic approach [94-96].

Music is known to be able, on its own, to trigger strong emotions, change the mood and help in the treatment of psychiatric and neurologic disorders [97]. Music has an effect on human brain, basic body functions and behavior suppressing stress [98, 99], correcting the state of consciousness $[100,101]$ and serving as a universal therapeutic remedy [102]. Music has particular efficacy, if being presented according to individual brain characteristic of a patient [103-105]. In our situation musical impact is organized in strict accordance with narrow-frequency EEG-oscillators functionally significant for a patient, owing to which treatment procedures assume peculiar healing properties [106].

The key advantage of the musical NFB technology is the possibility of its application to correct unfavorable functional states under conditions, which do not require conscious efforts of test subjects. It is of particular concern in treatment procedures with children and patients with specific psychiatric conditions or those with drug therapy contraindicated. Therefore, musical NFB technology was successfully tested to correct psychoemotional disorders in pregnancy and when watching out for labor [107, 108], as well as to eliminate stressinduced disorders [109]. Currently, there have been carried out the studies aimed at eliminating the signs of attention deficit-hyperactivity disorder in children by means of the present technology [110].

\section{Conclusion}

The carried out review of literature shows that, currently, neurointerface technologies are coming into use in medicine to substitute or recover useful functions in people incapable of performing these functions due to neuromuscular disorders or injuries, as well as to treat a wide range of diseases and disorders without medications.

Brain-computer interface technology enables to help compensate motor and sensory functions, contribute to the recovery of sensitivity of damaged body areas, makes it possible to perform an out-patient monitoring to detect and prevent potentially dangerous conditions (e.g., epileptic seizures). It will provide the recovery of some lost functions in paralyzed patients. Due to brain-computer interface technology paralyzed patients can, by acts of will, type on a monitor screen and press virtual on-off buttons available for their self-service of devices. Ultimately, by a multi-type cooperation of neurologists, psychologists, physicians, engineers and mathematicians the mentioned capabilities of braincomputer interface technology will be completed by accelerated education programs and targeted memory regeneration that will enable to extend significantly the sphere of its clinical application for both diagnostics of diseases and screening of risk groups, and also for effective correction of various pathological conditions.

Neurofeedback technology was initially oriented on clinical applications, and by now it has been successfully tested in treatment and correction of a large number of diseases and disorders ranging from attention deficithyperactivity disorder and autism to drug addiction and immunodeficiency. Despite a number of unsolved problems, by now a neurofeedback technology appears to be, at least, a very useful supplement for the existing treatment facilities. Looking forward, due to the development of more perfect research protocols, the use of modern technologies of human brain imaging and optimal organization of feedback signals (e.g., in the form of music), interface technologies can hold key positions in clinical practice.

Study Funding. The work was supported by Russian Foundation for Humanities, grants RFH No.15-06-10894 and 16-06-00133.

Conflicts of Interest. The authors have no conflicts of interest related to the present study.

\section{References}

1. Kaplan A.Ya., Kochetova A.G., Shishkin S.L., Basyul I.A., Ganin I.P., Vasilev A.N., Liburkina S.P. Experimental and theoretical foundations and practical implementation of technology brain-computer interface. Byulleten' sibirskoy meditsiny 2013; 12(2): 21-29.

2. Arns M., Heinrich H., Ros T., Rothenberger A., Strehl U. Editorial: neurofeedback in ADHD. Front Hum Neurosci 2015; 9: 602, https://doi.org/10.3389/fnhum.2015.00602.

3. Frederick J.A. Psychophysics of EEG alpha state 
discrimination. Conscious Cogn 2012; 21(3): 1345-1354, https://doi.org/10.1016/j.concog.2012.06.009.

4. Choi K. Electroencephalography (EEG)-based neurofeedback training for brain-computer interface $(\mathrm{BCl})$. Exp Brain Res 2013; 231(3): 351-365, https://doi.org/10.1007/ s00221-013-3699-6.

5. Huster R.J., Mokom Z.N., Enriquez-Geppert S., Herrmann C.S. Brain-computer interfaces for EEG neurofeedback: peculiarities and solutions. Int J Psychophysiol 2014; 91(1): 36-45, https://doi.org/10.1016/j. ijpsycho.2013.08.011.

6. Wood G., Kober S.E., Witte M., Neuper C. On the need to better specify the concept of "control" in brain-computerinterfaces/neurofeedback research. Front Syst Neurosci 2014; 8: 171, https://doi.org/10.3389/fnsys.2014.00171.

7. Johnston S.J., Boehm S.G., Healy D., Goebel R., Linden D.E.J. Neurofeedback: a promising tool for the selfregulation of emotion networks. Neurolmage 2010; 49(1): 1066-1072, https://doi.org/10.1016/j.neuroimage.2009.07.056.

8. Lofthouse N., Arnold L.E., Hurt E. Current status of neurofeedback for attention-deficit/hyperactivity disorder. Curr Psychiatry Rep 2012; 14(5): 536-542, https://doi.org/10.1007/ s11920-012-0301-z.

9. Nicolas-Alonso L.F., Gomez-Gil J. Brain computer interfaces, a review. Sensors 2012; 12(12): 1211-1279, https:// doi.org/10.3390/s120201211.

10. Minyaeva N.R. Noninvasive technologies in brain computer interface systems. Valeologiya 2012; 4: 29-31.

11. Arns M., Heinrich $H$., Strehl $U$. Evaluation of neurofeedback in ADHD: the long and winding road. Biol Psychol 2014; 95: 108-115, https://doi.org/10.1016/j. biopsycho.2013.11.013.

12. Gevensleben H., Moll G.H., Rothenberger A., Heinrich $H$. Neurofeedback in attention-deficit/hyperactivity disorder - different models, different ways of application. Front Hum Neurosci 2014; 8: 846, https://doi.org/10.3389/ fnhum.2014.00846.

13. Holtmann M., Sonuga-Barke E., Cortese S., Brandeis D. Neurofeedback for ADHD: a review of current evidence. Child Adolesc Psychiatr Clin N Am 2014; 23(4): 789-806, https://doi. org/10.1016/j.chc.2014.05.006.

14. Hurt E., Arnold L.E., Lofthouse N. Quantitative EEG neurofeedback for the treatment of pediatric attention-deficit/ hyperactivity disorder, autism spectrum disorders, learning disorders, and epilepsy. Child Adolesc Psychiatr Clin N Am 2014; 23(3): 465-486, https://doi.org/10.1016/j.chc.2014.02.001.

15. Linden D.E. Neurofeedback and networks of depression. Dialogues Clin Neurosci 2014; 16(1): 103-112.

16. Micoulaud-Franchi J.A., Geoffroy P.A., Fond G., Lopez R., Bioulac S., Philip P. EEG neurofeedback treatments in children with ADHD: an updated meta-analysis of randomized controlled trials. Front Hum Neurosci 2014; 8: 906 , https://doi.org/10.3389/fnhum.2014.00906.

17. Strehl $U$. What learning theories can teach us in designing neurofeedback treatments. Front Hum Neurosci 2014; 8: 894, https://doi.org/10.3389/fnhum.2014.00894.

18. Wander J.D., Rao R.P. Brain-computer interfaces: a powerful tool for scientific inquiry. Curr Opin Neurobiol 2014; 25: 70-75, https://doi.org/10.1016/j.conb.2013.11.013.

19. Shurkhay V.A., Aleksandrova E.V., Potapov A.A., Goryaynov S.A. The current state of the brain-computer interface problem. Voprosy neyrokhirurgii im. N.N. Burdenko 2015; 79(1): 97-104.
20. Huggins J.E., Moinuddin A.A., Chiodo A.E., Wren P.A. What would brain-computer interface users want: opinions and priorities of potential users with spinal cord injury. Arch Phys Med Rehabil 2015; 96(3): S38-S45.e5, https://doi. org/10.1016/j.apmr.2014.05.028.

21. Peters B., Bieker G., Heckman S.M., Huggins J.E., Wolf C., Zeitlin D., Fried-Oken M. Brain-computer interface users speak up: the Virtual Users' Forum at the 2013 International Brain-Computer Interface Meeting. Arch Phys Med Rehabil 2015; 96(3 Suppl): S33-S37, https://doi. org/10.1016/j.apmr.2014.03.037.

22. Jensen M.P., Sherlin L.H., Askew R.L., Fregni F., Witkop G., Gianas A., Howe J.D., Hakimian S. Effects of non-pharmacological pain treatments on brain states. Clin Neurophysiol 2013; 124(10): 2016-2024, https://doi. org/10.1016/j.clinph.2013.04.009.

23. Larsen S., Sherlin L. Neurofeedback: an emerging technology for treating central nervous system dysregulation. Psychiatr Clin North Am 2013; 36(1): 163-168, https://doi. org/10.1016/j.psc.2013.01.005.

24. Meisel V., Servera M., Garcia-Banda G., Cardo E., Moreno I. Neurofeedback and standard pharmacological intervention in ADHD: a randomized controlled trial with sixmonth follow-up. Biol Psychol 2013; 94(1): 12-21, https://doi. org/10.1016/j.biopsycho.2013.04.015.

25. Holtmann M., Pniewski B., Wachtlin D., Wörz S., Strehl U. Neurofeedback in children with attention-deficit/ hyperactivity disorder (ADHD) - a controlled multicenter study of a non-pharmacological treatment approach. BMC Pediatr 2014; 14(1): 202, https://doi.org/10.1186/1471-2431-14-202.

26. Johnson M.R. Fear of stimulant therapy for children and adolescents with attention-deficit/hyperactivity disorder. J Child Adolesc Psychopharmacol 2015; 25(2): 182, https://doi. org/10.1089/cap.2014.0117.

27. Haller S., Kopel R., Jhooti P., Haas T., Scharnowski F., Lovblad K.O., Scheffler K., Van De Ville D. Dynamic reconfiguration of human brain functional networks through neurofeedback. Neuroimage 2013; 81: 243-252, https://doi. org/10.1016/j.neuroimage.2013.05.019.

28. Burns A., Adeli H., Buford J.A. Brain-computer interface after nervous system injury. Neuroscientist 2014; 20(6): 639651, https://doi.org/10.1177/1073858414549015.

29. Bamdad M., Zarshenas H., Auais M.A. Application of $\mathrm{BCl}$ systems in neurorehabilitation: a scoping review. Disabil Rehabil Assist Technol 2015; 10(5): 355-364, https://doi.org/10. 3109/17483107.2014.961569.

30. Bowsher K., Civillico E.F., Coburn J., Collinger J., Contreras-Vidal J.L., Denison T., Donoghue J., French J., Getzoff N., Hochberg L.R., Hoffmann M., Judy J., Kleitman N., Knaack G., Krauthamer V., Ludwig K., Moynahan M., Pancrazio J.J., Peckham P.H., Pena C., Pinto V., Ryan T., Saha D., Scharen H., Shermer S., Skodacek K., Takmakov P., Tyler D., Vasudevan S., Wachrathit K., Weber D., Welle C.G., Ye M. Brain-computer interface devices for patients with paralysis and amputation: a meeting report. J Neural Eng 2016; 13(2): 023001, https://doi.org/10.1088/1741-2560/13/2/023001.

31. Daly J.J., Huggins J.E. Brain-computer interface: current and emerging rehabilitation applications. Arch Phys Med Rehabil 2015; 96(3): S1-S7, https://doi.org/10.1016/j.apmr.2015.01.007.

32. Vidal J.J. Toward direct brain-computer communication. Annu Rev Biophys Bioeng 1973; 2(1): 157-180, https://doi. org/10.1146/annurev.bb.02.060173.001105.

33. Gurfinkel' V.S., Malkin V.B., Tsetlin M.L., Shneyder A.Yu. 
Bioelektricheskoe upravlenie [Bioelectric control]. Moscow: Nauka; 1972; 244 p.

34. Bekhtereva N.P., Usov V.V. The technique of intermittent photostimulation in the rhythm of brain self potentials in ECG recording. Fiziologicheskiy zhurnal SSSR im. I.M. Sechenova 1960; 46(1): 108-111.

35. Kumano H., Horie H., Shidara T., Kuboki T., Suematsu H., Yasushi M. Treatment of a depressive disorder patient with EEG-driven photic stimulation. Biofeedback Self Regul 1996; 21(4): 323-334, https://doi.org/10.1007/bf02214432.

36. Kamei T., Toriumi Y., Kumano H., Fukada M., Matsumoto T. Use of photic feedback as an adjunct treatment in a case of miller fisher syndrome. Percept Mot Skills 2000; 90(1): 262-264, https://doi.org/10.2466/pms.90.1.262-264.

37. Woertz M., Pfurtscheller G., Klimesch W. Alpha power dependent light stimulation: dynamics of event-related (de) synchronization in human electroencephalogram. Brain Res Cogn Brain Res 2004; 20(2): 256-260, https://doi. org/10.1016/j.cogbrainres.2004.03.014.

38. Shih J.J., Krusienski D.J., Wolpaw J.R. Brain-computer interfaces in medicine. Mayo Clin Proc 2012; 87(3): 268-279, https://doi.org/10.1016/j.mayocp.2011.12.008.

39. Yanagisawa T., Hirata M., Saitoh Y., Kishima H., Matsushita K., Goto T., Fukuma R., Yokoi H., Kamitani Y., Yoshimine T. Electrocorticographic control of a prosthetic arm in paralyzed patients. Ann Neurol 2011; 71(3): 353-361, https://doi.org/10.1002/ana.22613.

40. Frolov A.A., Biryukova E.V., Bobrov P.D., Mokienko O.A., Platonov A.K., Pryanichnikov V.E., Chernikova L.A. Principles of neurorehabilitation based on the brain-computer interface and biologically adequate control of the exoskeleton. Hum Physiol 2013; 39(2): 196-208, https:// doi.org/10.1134/s0362119713020035.

41. Kaplan A.Y. The harmony of explosion: an interview. Otechestvennye zapiski 2014; 2(59): 123-136.

42. Levitskaya O.S., Lebedev M.A. Brain-computer interface: the future in the present. Vestnik Rossiyskogo gosudarstvennogo meditsinskogo universiteta 2016; 2: 4-16.

43. Hebert J.S., Olson J.L., Morhart M.J., Dawson M.R., Marasco P.D., Kuiken T.A., Chan K.M. Novel targeted sensory reinnervation technique to restore functional hand sensation after transhumeral amputation. IEEE Trans Neural Syst Rehabil Eng 2014; 22(4): 765-773, https://doi.org/10.1109/ tnsre.2013.2294907.

44. Kwok R. Neuroprosthetics: once more, with feeling. Nature 2013; 497(7448): 176-178, https://doi. org/10.1038/497176a.

45. Miranda R.A., Casebeer W.D., Hein A.M., Judy J.W., Krotkov E.P., Laabs T.L., Manzo J.E., Pankratz K.G., Pratt G.A., Sanchez J.C., Weber D.J., Wheeler T.L., Ling G.S. DARPA-funded efforts in the development of novel braincomputer interface technologies. J Neurosci Methods 2015; 244: 52-67, https://doi.org/10.1016/j.jneumeth.2014.07.019.

46. Ganin I.P., Shishkin S.L., Kaplan A.Y. A P300-based brain-computer interface with stimuli on moving objects: four-session single-trial and triple-trial tests with a gamelike task design. PLoS One 2013; 8(10): e77755, https://doi. org/10.1371/journal.pone.0077755.

47. Mokienko O.A., Lyukmanov R.K., Chernikova L.A., Suponeva N.A., Piradov M.A., Frolov A.A. Brain-computer interface: the first experience of clinical use in Russia. Hum Physiol 2016; 42(1): 24-31, https://doi.org/10.1134/ s0362119716010126.
48. Frolov A.A., Mokienko O.A., Lyukmanov R.Kh., Chernikova L.A., Kotov S.V., Turbina L.G., Bobrov P.D., Biryukova E.V., Kondur A.A., Ivanova G.E., Staritsyn A.N., Bushkova Yu.V., Dzhalagoniya I.Z., Kurganskaya M.E., Pavlova O.G., Budilin S.Yu., Aziatskaya G.A., Khizhnikova A.E., Chervyakov A.V., Lukyanov A.L., Nadareyshvily G.G. Preliminary results of a controlled study of $\mathrm{BCl}$-exoskeleton technology efficacy in patients with poststroke arm paresis. Vestnik Rossiyskogo gosudarstvennogo meditsinskogo universiteta 2016; 2: 17-25.

49. Frolov A.A., Husek D., Silchenko A.V., Tintera J., Rydlo J. The changes in the hemodynamic activity of the brain during motor imagery training with the use of braincomputer interface. Hum Physiol 2016; 42(1): 1-12, https://doi. org/10.1134/s0362119716010084.

50. Shishkin S.L., Kozyrskiy B.L., Trofimov A.G., Nuzhdin Y.O., Federova A.A., Svirin E.P., Velichkovsky B.M. Improving eye-brain-computer interface performance by using electroencephalogram frequency components. Vestnik Rossiyskogo gosudarstvennogo meditsinskogo universiteta 2016; 2: 39-44.

51. Bradberry T.J., Gentili R.J., Contreras-Vidal J.L. Fast attainment of computer cursor control with noninvasively acquired brain signals. J Neural Eng 2011; 8(3): 036010, https://doi.org/10.1088/1741-2560/8/3/036010.

52. Kaplan A.Y. Neurophysiological foundations and practical realizations of the brain-machine interfaces in the technology in neurological rehabilitation. Hum Physiol 2016; 42(1): 103-110, https://doi.org/10.1134/s0362119716010102.

53. Hammond D.C. What is neurofeedback: an update. J Neurother 2011; 15(4): 305-336, https://doi.org/10.1080/108 74208.2011.623090.

54. Kamiya J. The first communications about operant conditioning of the EEG. J Neurother 2011; 15(1): 65-73, https://doi.org/10.1080/10874208.2011.545764.

55. Ghaziri J., Tucholka A., Larue V., BlanchetteSylvestre M., Reyburn G., Gilbert G., Lévesque J., Beauregard M. Neurofeedback training induces changes in white and gray matter. Clin EEG Neurosci 2013; 44(4): 265272, https://doi.org/10.1177/1550059413476031.

56. Seitz A.R. Cognitive Neuroscience: Targeting neuroplasticity with neural decoding and biofeedback. Curr Biol 2013; 23(5): R210-R212, https://doi.org/10.1016/j. cub.2013.01.015.

57. Aslanyan E.V., Kiroy V.N., Stoletniy A.S., Lazurenko D.M., Bahtin O.M., Minyaeva N.R., Kiroy R.I. Impact of individual personality features on ability to voluntary regulation of expression EEG alpha and beta frequencies. Rossiyskiy fiziologicheskiy zhurnal im. I.M. Sechenova 2015; 101(5): 599-613.

58. Kiroy V.N., Lazurenko D.M., Shepelev I.E., Minyaeva N.R., Aslanyan E.V., Bakhtin O.M., Shaposhnikov D.G., Vladimirskiy B.M. Changes in EEG spectral characteristics in the course of neurofeedback training. Hum Physiol 2015; 41(3): 269-279, https://doi.org/10.1134/ s0362119715030081.

59. Niv S. Clinical efficacy and potential mechanisms of neurofeedback. Pers Individ Dif 2013; 54(6): 676-686, https:// doi.org/10.1016/j.paid.2012.11.037.

60. Ros T., Baars J.B., Lanius R.A., Vuilleumier P. Tuning pathological brain oscillations with neurofeedback: a systems neuroscience framework. Front Hum Neurosci 2014; 8: 1008, https://doi.org/10.3389/fnhum.2014.01008. 
61. Arnold L.E., Lofthouse N., Hersch S., Pan X., Hurt E., Bates B., Kassouf K., Moone S., Grantier C. EEG neurofeedback for ADHD: double-blind sham-controlled randomized pilot feasibility trial. J Atten Disord 2012; 17(5): 410-419, https://doi.org/10.1177/1087054712446173.

62. Gevensleben H., Kleemeyer M., Rothenberger L.G., Studer P., Flaig-Röhr A., Moll G.H., Rothenberger A., Heinrich $H$. Neurofeedback in ADHD: further pieces of the puzzle. Brain Topogr 2014; 27(1): 20-32, https://doi. org/10.1007/s10548-013-0285-y.

63. Escolano C., Navarro-Gil M., Garcia-Campayo J., Congedo M., Minguez J. The effects of individual upper alpha neurofeedback in ADHD: an open-label pilot study. Appl Psychophysiol Biofeedback 2014; 39(3-4): 193-202, https:// doi.org/10.1007/s10484-014-9257-6.

64. Duric N.S., Aßmus J., Elgen I.B. Self-reported efficacy of neurofeedback treatment in a clinical randomized controlled study of ADHD children and adolescents. Neuropsychiatr Dis Treat 2014; 10: 1645-1645, https://doi.org/10.2147/ndt.s66466.

65. Bink M., van Nieuwenhuizen C., Popma A., Bongers I.L., van Boxtel G.J.M. Neurocognitive effects of neurofeedback in adolescents with ADHD. J Clin Psychiatry 2014; 75(05): 535-542, https://doi.org/10.4088/jcp.13m08590.

66. Cannon R.L., Pigott H.E., Surmeli T., Simkin D.R., Thatcher R.W., Van den Bergh W., Gluck G., Lubar J.F., Davis R., Foster D.S., Douglas J., Malcolm A.T., Bars D., Little K., Center W., Berman M., Russell H., Hammer B., Koberda J.L. The problem of patient heterogeneity and lack of proper training in a study of EEG neurofeedback in children. J Clin Psychiatry 2014; 75(3): 289-290, https://doi. org/10.4088/jcp.13lr08850.

67. Lee Y.-S., Bae S.-H., Lee S.-H., Kim K.-Y. Neurofeedback training improves the dual-task performance ability in stroke patients. Tohoku J Exp Med 2015; 236(1): 8188, https://doi.org/10.1620/tjem.236.81.

68. Peskind E.R., Brody D., Cernak I., McKee A., Ruff R.L. Military- and sports-related mild traumatic brain injury. J Clin Psychiatry 2013; 74(8): e17, https://doi.org/10.4088/ jcp.12011nr2c.

69. Strehl U., Birkle S.M., Wörz S., Kotchoubey B. Sustained reduction of seizures in patients with intractable epilepsy after self-regulation training of slow cortical potentials - 10 years after. Front Hum Neurosci 2014; 8: 604, https://doi.org/10.3389/fnhum.2014.00604.

70. Ross S.M. Neurofeedback. Holist Nurs Pract 2013; 27(4): 246-250, https://doi.org/10.1097/hnp.0b013e3182971b7c.

71. Unterrainer H.F., Lewis A.J., Gruzelier J.H. EEGneurofeedback in psychodynamic treatment of substance dependence. Front Psychol 2013; 4: 692, https://doi. org/10.3389/fpsyg.2013.00692.

72. Dehghani-Arani F., Rostami R., Nadali $H$. Neurofeedback training for opiate addiction: improvement of mental health and craving. Appl Psychophysiol Biofeedback 2013; 38(2): 133-141, https://doi.org/10.1007/s10484-0139218-5.

73. Peeters F., Oehlen M., Ronner J., van Os J., Lousberg R. Neurofeedback as a treatment for major depressive disorder - a pilot study. PLoS One 2014; 9(3): e91837, https://doi.org/10.1371/journal.pone.0091837.

74. Pineda J.A., Juavinett A., Datko M. Self-regulation of brain oscillations as a treatment for aberrant brain connections in children with autism. Med Hypotheses 2012; 79(6): 790798, https://doi.org/10.1016/j.mehy.2012.08.031.
75. Sorokina N.D., Selitskii G.V. Tension headache and migraine: efficacy of biological feed-back in their treatment. Zhurnal nevrologii i psikhiatrii im. S.S. Korsakova 2013; 113(4): 86-91.

76. Bartholdy S., Musiat P., Campbell I.C., Schmidt U. The potential of neurofeedback in the treatment of eating disorders: a review of the literature. Eur Eat Disord Rev 2013; 21(6): 456463, https://doi.org/10.1002/erv.2250.

77. Jensen M.P., Day M.A., Miró J. Neuromodulatory treatments for chronic pain: efficacy and mechanisms. Nat Rev Neurol 2014; 10(3): 167-178, https://doi.org/10.1038/ nrneurol.2014.12.

78. Hassan M.A., Fraser M., Conway B.A., Allan D.B., Vuckovic $A$. The mechanism of neurofeedback training for treatment of central neuropathic pain in paraplegia: a pilot study. BMC Neurol 2015; 15(1), https://doi.org/10.1186/ s12883-015-0445-7.

79. Schoenberg P.L.A., David A.S. Biofeedback for psychiatric disorders: a systematic review. Appl Psychophysiol Biofeedback 2014; 39(2): 109-135, https://doi.org/10.1007/ s10484-014-9246-9.

80. Farkas A., Bluschke A., Roessner V., Beste C. Neurofeedback and its possible relevance for the treatment of Tourette syndrome. Neurosci Biobehav Rev 2015; 51: 87-99, https://doi.org/10.1016/j.neubiorev.2015.01.012.

81. Graczyk M., Pąchalska M., Ziółkowski A., Mańko G., Łukaszewska B., Kochanowicz K., Mirski A., Kropotov I.D. Neurofeedback training for peak performance. Ann Agric Environ Med 2014; 21(4): 871-875, https://doi. org/10.5604/12321966.1129950.

82. Ruiz S., Birbaumer N., Sitaram R. Editorial: learned brain self-regulation for emotional processing and attentional modulation: from theory to clinical applications. Front Behav Neurosci 2016; 10, https://doi.org/10.3389/fnbeh.2016.00062.

83. Hayashibe M., Guiraud D., Pons J.L., Farina D. Editorial: biosignal processing and computational methods to enhance sensory motor neuroprosthetics. Front Neurosci 2015; 9: 434, https://doi.org/10.3389/fnins.2015.00434.

84. Thibault R.T., Lifshitz M., Raz A. The self-regulating brain and neurofeedback: experimental science and clinical promise. Cortex 2016; 74: 247-261, https://doi.org/10.1016/j. cortex.2015.10.024.

85. Hammond D.C. The need for individualization in neurofeedback: heterogeneity in QEEG patterns associated with diagnoses and symptoms. Appl Psychophysiol Biofeedback 2009; 35(1): 31-36, https://doi.org/10.1007/ s10484-009-9106-1.

86. Lazareva O.Yu., Bazanova O.M. The effects of instructions on the efficiency of EEG alpha power voluntary increase training. Byulleten' sibirskoy meditsiny 2013; 12(2): 58-65.

87. Sokhadze E.M., El-Baz A.S., Tasman A., Sears L.L., Wang Y., Lamina E.V., Casanova M.F. Neuromodulation integrating rTMS and neurofeedback for the treatment of autism spectrum disorder: an exploratory study. Appl Psychophysiol Biofeedback 2014; 39(3-4): 237-257, https:// doi.org/10.1007/s10484-014-9264-7.

88. Tang H.-Y., Vitiello M.V., Perlis M., Riegel B. OpenLoop neurofeedback audiovisual stimulation: a pilot study of its potential for sleep induction in older adults. Appl Psychophysiol Biofeedback 2015; 40(3): 183-188, https://doi.org/10.1007/ s10484-015-9285-x.

89. Fedotchev A.I. Efficacy of EEG biofeedback 
procedures in correcting stress-related functional disorders. Hum Physiol 2010; 36(1): 86-90, https://doi.org/10.1134/ s0362119710010111.

90. Gruzelier J.H. EEG-neurofeedback for optimising performance. III: a review of methodological and theoretical considerations. Neurosci Biobehav Rev 2014; 44: 159-182, https://doi.org/10.1016/j.neubiorev.2014.03.015.

91. Friedrich E.V., Suttie N., Sivanathan A., Lim T., Louchart S., Pineda J.A. Brain-computer interface game applications for combined neurofeedback and biofeedback treatment for children on the autism spectrum. Front Neuroeng 2014; 7: 21, https://doi.org/10.3389/fneng.2014.00021.

92. Fedotchev A.I., Oh S.J., Semikin G.I. Combination of neurofeedback technique with music therapy for effective correction of stress-induced disorders. Sovremennye tehnologii $v$ medicine 2014 ; 6(3): 60-63.

93. Fedotchev A.I., Bondar A.T., Bakhchina A.V., Grigorieva V.N., Katayev A.A., Parin S.B., Radchenko G.S., Polevaya S.A. Transformation of patient's EEG oscillators into music-like signals for correction of stress-induced functional states. Sovremennye tehnologii v medicine 2016; 8(1): 93-98, https://doi.org/10.17691/stm2016.8.1.12.

94. Fedotchev A.I. Analysis of resonance EEG reactions in estimating the effectiveness of sensor exposure. Fiziologiya cheloveka 1997; 23(4): 117-123.

95. Fedotchev A.I., Bondar A.T., Akoev I.G. Human EEG spectral structure investigation: modern state of the art and the tendencies. Uspekhi fiziologicheskikh nauk 2000; 31(3): 39-53.

96. Fedotchev A.I., Bondar' A.T., Matrusov S.G., Semenov V.S., Soin A.G. Utilization of feedback signals from patient's own endogenous rhythms for non-drug correction of human functional disturbances. Uspekhi fiziologicheskikh nauk 2006; 37(4): 82-93.

97. Koelsch S. Brain correlates of music-evoked emotions. Nat Rev Neurosci 2014; 15(3): 170-180, https://doi. org/10.1038/nrn3666.

98. Thoma M.V., La Marca R., Brönnimann R., Finkel L., Ehlert U., Nater U.M. The effect of music on the human stress response. PLoS One 2013; 8(8): e70156, https://doi. org/10.1371/journal.pone.0070156.

99. Radstaak M., Geurts S.A.E., Brosschot J.F., Kompier M.A.J. Music and psychophysiological recovery from stress. Psychosom Med 2014; 76(7): 529-537, https://doi. org/10.1097/psy.0000000000000094.

100. Rollnik J.D., Altenmüller E. Music in disorders of consciousness. Front Neurosci 2014; 8, https://doi. org/10.3389/fnins.2014.00190.

101. Clark C.N., Downey L.E., Warren J.D. Brain disorders and the biological role of music. Soc Cogn Affect Neurosci 2014; 10(3): 444-452, https://doi.org/10.1093/scan/nsu079.

102. Gray E. In practice: music: a therapy for all? Perspect Public Health 2013; 133(1): 14, https://doi. org/10.1177/1757913912468642.

103. Höller Y., Thomschewski A., Schmid E.V., Höller P., Crone J.S., Trinka E. Individual brain-frequency responses to self-selected music. Int J Psychophysiol 2012; 86(3): 206-213, https://doi.org/10.1016/j.ijpsycho.2012.09.005.

104. Park M., Hennig-Fast K., Bao Y., Carl P., Pöppel E., Welker L., Reiser M., Meindl T., Gutyrchik E. Personality traits modulate neural responses to emotions expressed in music. Brain Res 2013; 1523: 68-76, https://doi.org/10.1016/j. brainres.2013.05.042.

105. Müller W., Haffelder G., Schlotmann A., Schaefers A.T.U., Teuchert-Noodt G. Amelioration of psychiatric symptoms through exposure to music individually adapted to brain rhythm disorders - a randomised clinical trial on the basis of fundamental research. Cogn Neuropsychiatry 2014; 19(5): 399-413, https://doi.org/10.1080/13546805.2013.879054.

106. Fedotchev A.I., Bondar' A.T., Bakhchina A.V., Parin S.B., Polevaya S.A., Radchenko G.S. Music-acoustic signals controlled by subject's brain potentials in the correction of unfavorable functional states. Uspekhi fiziologicheskikh nauk 2016; 47(1): 69-79.

107. Fedotchev A.I., Kim E.V. Correction of functional disturbances during pregnancy by the method of adaptive EEG biofeedback training. Hum Physiol 2006; 32(6): 652-656, https://doi.org/10.1134/s0362119706060041.

108. Fedotchev A.I., Kim E.V. Peculiarities of biocontrol treatment sessions with electroencephalogram feedback in physiological and aggravated pregnancies. Zhurnal vysshey nervnoy deyatel'nosti im. I.P. Pavlova 2009; 59(4): 421-428.

109. Fedotshev A.I. Stress, the consequences of its influence on humans and modern non-drug methods of stressinduced states reduction. Uspekhi fiziologicheskikh nauk 2009; 40(1): 77-91.

110. Fedotchev A.I., Zemlyanaya A.A., Polevaya S.A., Savchuk L.V. Attention deficit hyperactivity disorder and current possibilities of its treatment by the method of neurofeedback training. Zhurnal nevrologii $i$ psikhiatrii im. S.S. Korsakova 2016; 116(5): 98, https://doi.org/10.17116/ jnevro20161165198-101. 